\title{
Terrestrial invasion of pomatiopsid gastropods in the heavy-snow region of the Japanese Archipelago
}

\author{
Yuichi Kameda* and Makoto Kato
}

\begin{abstract}
Background: Gastropod mollusks are one of the most successful animals that have diversified in the fully terrestrial habitat. They have evolved terrestrial taxa in more than nine lineages, most of which originated during the Paleozoic or Mesozoic. The rissooidean gastropod family Pomatiopsidae is one of the few groups that have evolved fully terrestrial taxa during the late Cenozoic. The pomatiopsine diversity is particularly high in the Japanese Archipelago and the terrestrial taxa occur only in this region. In this study, we conducted thorough samplings of Japanese pomatiopsid species and performed molecular phylogenetic analyses to explore the patterns of diversification and terrestrial invasion.

Results: Molecular phylogenetic analyses revealed that Japanese Pomatiopsinae derived from multiple colonization of the Eurasian Continent and that subsequent habitat shifts from aquatic to terrestrial life occurred at least twice within two Japanese endemic lineages. Each lineage comprises amphibious and terrestrial species, both of which are confined to the mountains in heavy-snow regions facing the Japan Sea. The estimated divergence time suggested that diversification of these terrestrial lineages started in the Late Miocene, when active orogenesis of the Japanese landmass and establishment of snowy conditions began.

Conclusions: The terrestrial invasion of Japanese Pomatiopsinae occurred at least twice beside the mountain streamlets of heavy-snow regions, which is considered the first case of this event in the area. Because snow coverage maintains stable temperatures and high humidity on the ground surface, heavy-snow conditions may have paved the way for these organisms from freshwater to land via mountain streamlets by preventing winter desiccation in mountain valleys. The fact that the terrestrialization of Pomatiopsidae occurred only in year-round wet environments, but not in seasonally dried regions, provides new insight into ancient molluscan terrestrialization.
\end{abstract}

\section{Background}

Terrestrial invasion is one of the most important events in the history of life $[1,2]$. Terrestrial lineages evolved in seven animal phyla, among which vertebrates, arthropods, and mollusks are representatives of more successful groups of the epifaunal terrestrial life [3]. Most terrestrial lineages are considered to have originated under mild or tropical climate during the Paleozoic and Mesozoic, whereas few animals became fully terrestrial during the Cenozoic [3,4]. In regard to this point, mollusks are especially unique due to several fully terrestrial

\footnotetext{
* Correspondence: yuichi.c.kameda@gmail.com

Graduate School of Human and Environmental Studies, Kyoto University, Yoshida-nihonmatsu-cho, Sakyo, Kyoto 606-8501, Japan
}

and epifaunal lineages that evolved during the Cenozoic $[5,6]$.

Terrestrial invasion of gastropod mollusks has occurred in Neritopsina, Cyclophoroidea, Littorinoidea, Rissooidea, Ellobioidea, Onchidioidea, Rathouisioidea, Succineoidea, and Stylommatophora $[7,8]$, and in particular, each of Neritopsina, Rissooidea and Ellobioidea has likely achieved land invasion more than once $[6,8,9]$. Most terrestrialization events have occurred during the Paleozoic or Mesozoic [2,8-10], and only some members of rissooidean families Truncatellidae, Assimineidae, and Pomatiopsidae are considered to have colonized to land during the Cenozoic $[5,6,11,12]$. Most truncatellid and assimineid snails amphibiously live in intertidal and

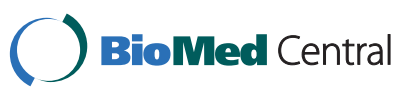


supratidal zones from brackish water to pelagic areas. Terrestrial lineages likely evolved from such ancestors $[4,6]$. In contrast, most pomatiopsid snails live in freshwater habitats $[11,13]$. Therefore, the process of terrestrial invasion in Pomatiopsidae might differ from those of former families.

Pomatiopsidae, which are well known as intermediate hosts of Asian schistosomes [14-18], comprises two subfamilies, Triculinae and Pomatiopsinae. The former radiated as aquatic snails in freshwater habitats in Southeast Asia [11,19], whereas the latter are distributed worldwide (Figure 1) and possesses various lifestyles from aquatic to amphibious, littoral, halophilic, and even terrestrial $[11,20]$. The generic diversity of Pomatiopsinae is particularly high in the Japanese Archipelago, where four of the eight genera including two endemics, are recorded (Figures 1 \&2) [11]. The diversity of Japanese Pomatiopsinae is based on two characteristics, i.e. unique habitats of the endemic genera, and their distribution.

One of the two Japanese endemic genera, Fukuia, live amphibiously around rocky walls of steep valleys covered with ferns and bryophytes, and moistened by dripping water $[21,22]$. They inhabit only along the mountain streamlets, where such habitats are typically found, and often occur with pleurocerid freshwater snails [21]. In contrast, the other endemic genus Blanfordia is the sole terrestrial group within Pomatiopsidae (Figure 1) [11]. They are found on forest floor and tree trunks in coastal to mountainous areas (Table 1) [11,22], together with fully terrestrial gastropod snails such as diplommatinids, camaenids and bradybaenids. The distribution of the two genera are largely confined to the heavy-snow region facing the Japan Sea (Figures 3A-C) [22]. Generally, East Asia is dominated by a monsoon climate, characterized by alternating hot rainy summers and cold dry winters [23]. The snow-rich area is unique in that winter monsoons blowing southward from the Japan Sea and high mountain ranges shaping the Japanese Archipelago bring enormous snowfalls in winter $[24,25]$. Such a varied climate harbors various unique flora and fauna [26,27], and can be closely related to the diversification of Pomatiopsinae in the archipelago.

In this study, we provide the first molecular phylogeny encompassing all pomatiopsid taxa occurring on the Japanese Archipelago. We also analyzed the relationship with continental taxa. In addition, we estimated the timing of diversification and terrestrial invasion, which can be interpreted using the geological history of Japan. Based on these results, we discuss the reason why the terrestrial invasion of Pomatiopsidae occurred only in the Japanese Archipelago.

\section{Results}

\section{Phylogenetic analyses}

To investigate the evolutionary history of pomatiopsid snails in the Japanese Archipelago, we sequenced the

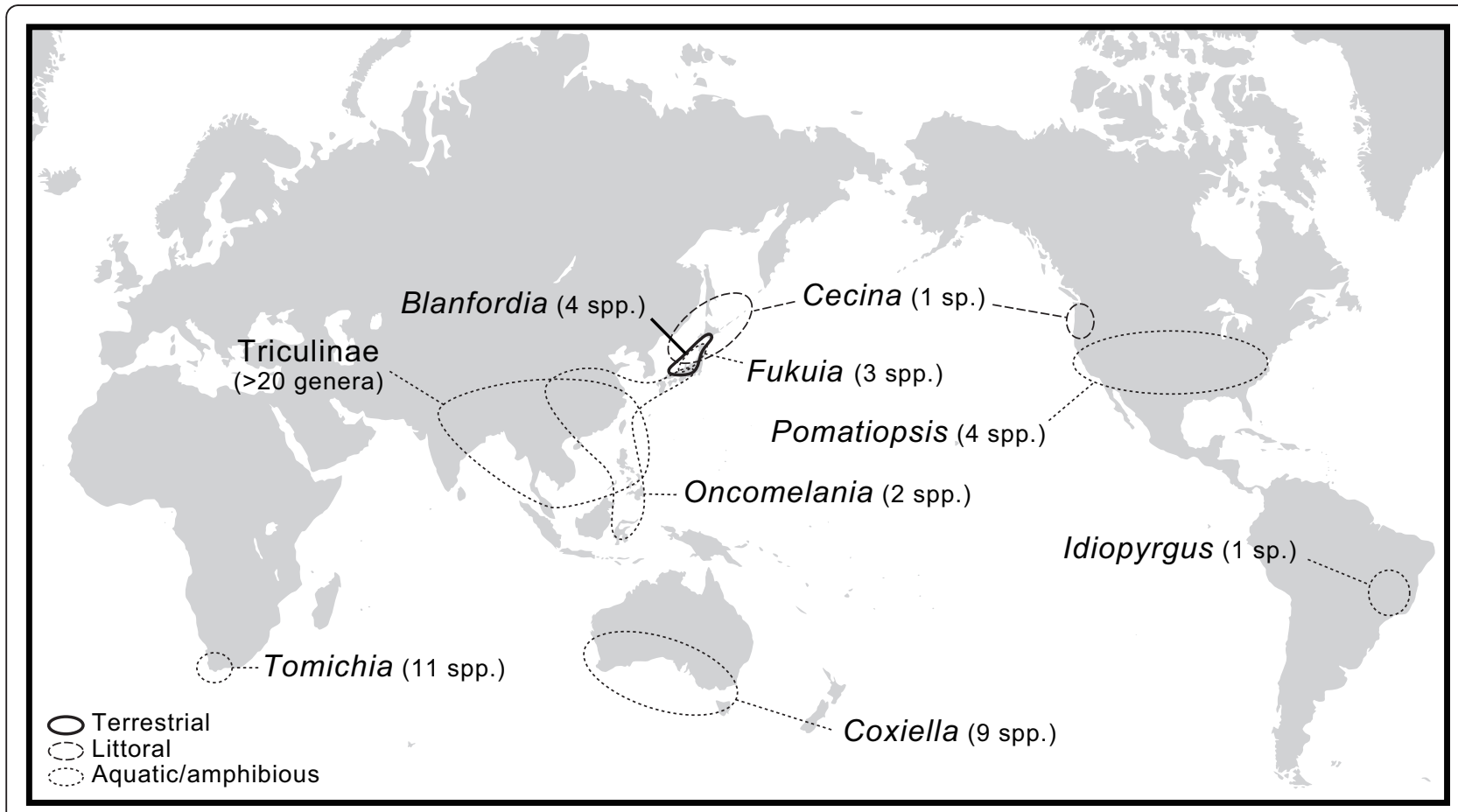

Figure 1 A map showing worldwide distribution of Pomatiopsine genera and Triculinae (after Davis [11]). Terrestrial taxa occur only on the Japanese Archipelago located in East Asia (Blanfordia). Tomichia and Coxiella include several halophilic species occuring on saline lakes. 

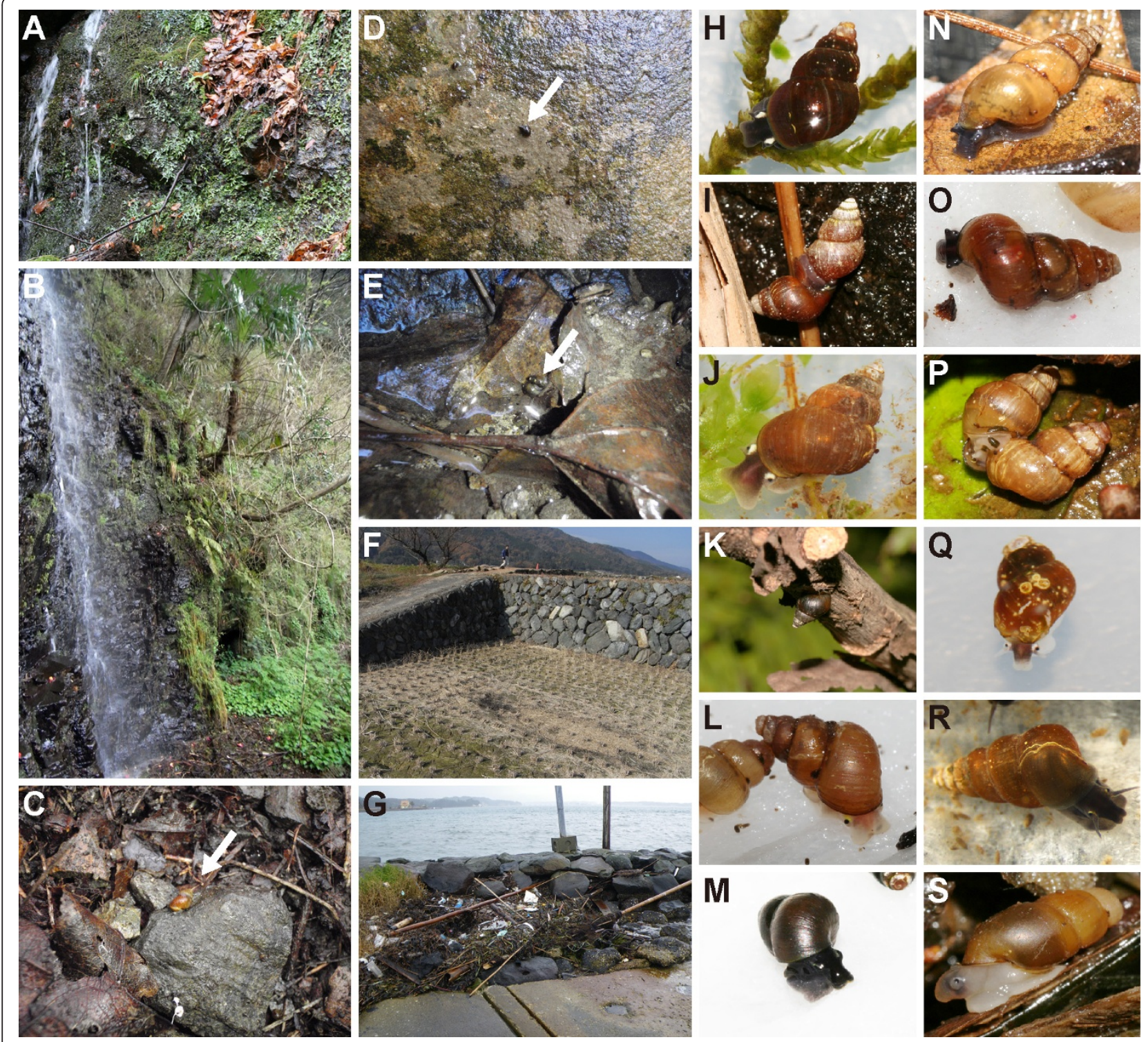

Figure 2 Japanese pomatiopsine snails and their habitats. A. Dripping rocks beside the waterfall covered with bryophytes, inhabited by amphibious species F. kurodai. B. Habitats of amphibious species F. multistriata (beside the waterfall) and terrestrial species B. simplex (forest floor). C. Terrestrial species B. japonica on the forest floor. D. Aquatic species F. ooyagii clinging to wet rocky wall. E. Aquatic species $O$. minima inhabiting mountain streamlet. F. Rice field (dry season) inhabited by seasonally amphibious species $O$. h. nosophora. G. Decaying seaweed stranded on the beach, inhabited by C. manchurica. H. F. kurodai niigataensis. I. F. k. kurodai mating outside the water film. J. F. multistriata. K. F. multistriata resting on a tree branch. L. B. integra (terrestrial). M. F. ooyagii. N. B. sp. (terrestrial). O. B. bensoni (terrestrial). P. B. simplex mating on the forest floor. Q. O. minima. R. O. h. nosophora. S. C. manchurica found among decaying seaweeds.

mitochondrial cytochrome oxidase subunit 1 (CO1), $16 \mathrm{~S}$ ribosomal RNA genes, and nuclear $18 \mathrm{~S}$ and $28 \mathrm{~S}$ rRNA regions (Table 1). Maximum parsimony (MP) analysis of the combined data resulted in a single most parsimonious tree (3375 steps, consistency index excluding uninformative characters $[\mathrm{CI}]=0.3861$, retention index $[R I]=0.6567)$. The results of maximum likelihood (ML) and Bayesian analyses were largely consistent with the relatively well supported clades. Only posterior probabilities of $P \geq 0.95$ and bootstrap support values of $P \geq 75$ were considered statistically significant. Hence, support values below this significance level are not discussed.

The phylogenetic analyses recovered Pomatiopsidae as a monophyletic clade (Figure 4). Triculinae was also confirmed as monophyletic. On the other hand, relationships among most of the pomatiopsine genera are not well resolved, although the pomatiopsine genus 
Table 1 Sampling information of specimens used in the present study

\begin{tabular}{|c|c|c|c|c|c|c|}
\hline Taxon & Habitat & Locality & $18 S$ & $28 S$ & $16 S$ & $\mathrm{COI}$ \\
\hline \multicolumn{7}{|l|}{ POMATIOPSIDAE } \\
\hline \multicolumn{7}{|l|}{ Pomatiopsinae } \\
\hline \multirow[t]{2}{*}{ Blanfordia bensoni (Adams, 1861) } & Inland forests; terrestrial & $\begin{array}{l}\text { Nigorikawa, Mori, } \\
\text { Hokkaido }\end{array}$ & AB611708* & AB611709* & AB611710* & $\mathrm{AB} 611711^{*}$ \\
\hline & & $\begin{array}{l}\text { Futoro, Setana, } \\
\text { Hokkaido }\end{array}$ & AB611712* & AB611713* & AB611714* & AB611715* \\
\hline \multirow[t]{2}{*}{ Blanfordia integra Pilsbry, 1924} & $\begin{array}{l}\text { Inland forests; terrestrial, often } \\
\text { arboreal }\end{array}$ & Mt. Mikuni, Shizuoka & AB611716* & AB611717* & AB611718* & AB611719* \\
\hline & & Nou, Itoigawa, Niigata & AB611720* & $\mathrm{AB} 611721^{*}$ & AB611722* & AB611723* \\
\hline Blanfordia japonica (Adams, 1861) & Coastal to inland forests; terrestrial & Sado, Niigata ${ }^{1}$ & AB611724* & AB611725* & AB611726* & $A B 611727^{*}$ \\
\hline \multirow[t]{2}{*}{ Blanfordia simplex Pilsbry, 1902} & $\begin{array}{l}\text { Coastal dunes and littoral forests; } \\
\text { terrestrial }\end{array}$ & $\begin{array}{l}\text { Yunohama, Tsuruoka, } \\
\text { Yamagata? }\end{array}$ & AB611728* & AB611729* & AB611730* & $A B 611731^{*}$ \\
\hline & & Ayukawa, Fukui, Fukui & AB611732* & AB611733* & AB611734* & AB611735* \\
\hline Blanfordia sp. & Inland forests; terrestrial & Samani, Hokkaido & AB611736* & AB611737* & AB611738* & AB611739* \\
\hline \multirow[t]{2}{*}{ Cecina manchurica Adams, 1861} & Littoral & Nanao, Ishikawa & AB611740* & AB611741* & AB611742* & AB611743* \\
\hline & & Betsukai, Hokkaido & AB611744* & AB611745* & AB611746* & $\mathrm{AB} 611747^{*}$ \\
\hline \multirow[t]{5}{*}{$\begin{array}{l}\text { Fukuia kurodai kurodai Abbott \& } \\
\text { Hunter, } 1949\end{array}$} & $\begin{array}{l}\text { Mountain streamlets; amphibious, } \\
\text { often arboreal }\end{array}$ & $\begin{array}{l}\text { Ohyana, Yurihonjo, } \\
\text { Akita }\end{array}$ & AB611748* & AB611749* & AB611750* & AB611751* \\
\hline & & $\begin{array}{l}\text { Atsumi, Tsuruoka, } \\
\text { Yamagata }\end{array}$ & AB611752* & AB611753* & AB611754* & AB611755* \\
\hline & & $\begin{array}{l}\text { Kitamata, Sakata, } \\
\text { Yamagata }\end{array}$ & AB611756* & AB611757* & AB611758* & AB611759* \\
\hline & & $\begin{array}{l}\text { Shimouchinami, Ohno, } \\
\text { Fukui }\end{array}$ & AB611760* & AB611761* & AB611762* & AB611763* \\
\hline & & $\begin{array}{l}\text { Takeda, Maruoka, Sakai, } \\
\text { Fukuil }^{2}\end{array}$ & AB611764* & AB611765* & AB611766* & $\mathrm{AB} 611767^{*}$ \\
\hline \multirow[t]{2}{*}{$\begin{array}{l}\text { Fukuia kurodai niigataensis Minato, } \\
1973\end{array}$} & $\begin{array}{l}\text { Mountain streamlets; amphibious, } \\
\text { often arboreal }\end{array}$ & $\begin{array}{l}\text { Oyachi, Itoigawa, } \\
\text { Niigata }\end{array}$ & AB611768* & AB611769* & AB611770* & $A B 611771^{*}$ \\
\hline & & $\begin{array}{l}\text { Ikazuchi, Murakami, } \\
\text { Niigata }\end{array}$ & AB611772* & AB611773* & AB611774* & AB611775* \\
\hline $\begin{array}{l}\text { Fukuia multistriata Abbott \& Hunter, } \\
1949\end{array}$ & $\begin{array}{l}\text { Mountain streamlets; amphibious, } \\
\text { often arboreal }\end{array}$ & Umeura, Echizen, Fukui & AB611776* & AB611777* & AB611778* & AB611779* \\
\hline Fukuia ooyagii Minato, 1982 & Mountain streamlets; aquatic & Iwaya, Mutsu, Aomori ${ }^{1}$ & AB611780* & AB611781* & AB611782* & AB611783* \\
\hline $\begin{array}{l}\text { Oncomelania hupensis nosophora } \\
\text { (Robson, 1915) }\end{array}$ & $\begin{array}{l}\text { Lakes/marshy ground; seasonally } \\
\text { amphibious }\end{array}$ & Nirasaki, Yamanashi & AB611784* & AB611785* & AB611786* & $\mathrm{AB} 611787^{*}$ \\
\hline $\begin{array}{l}\text { Oncomelania hupensis quadrasi } \\
\text { (Möllendorff, 1895) }\end{array}$ & $\begin{array}{l}\text { Lakes/marshy ground; seasonally } \\
\text { amphibious }\end{array}$ & Genbank & - & - & DQ212862 & DQ112287 \\
\hline $\begin{array}{l}\text { Oncomelania hupensis robertsoni } \\
\text { Bartsch, } 1946\end{array}$ & $\begin{array}{l}\text { Lakes/marshy ground; seasonally } \\
\text { amphibious }\end{array}$ & Genbank & AF212906 & AY207042 & AF212893 & AF213339 \\
\hline \multirow[t]{2}{*}{ Oncomelania minima (Bartsch, 1936) } & Mountain streamlets; aquatic & Wajima, Ishikawa & AB611788* & AB611789* & AB611790* & AB611791* \\
\hline & & Sado, Niigata & AB611792* & AB611793* & AB611794* & AB611795* \\
\hline Pomatiopsis lapidaria (Say, 1817) & Marshy ground; amphibious & Genbank & AF367666 & - & AY676118 & AF367636 \\
\hline \multicolumn{7}{|l|}{ Triculinae } \\
\hline $\begin{array}{l}\text { Gammatricula fujianensis (Liu, Zhang } \\
\text { \& Wang, 1983) }\end{array}$ & Aquatic & Genbank & AF212909 & - & AF212896 & AF213342 \\
\hline Gammatricula shini (Habe, 1961) & Aquatic & Yonaguni Isl., Okinawa & AB611796* & AB611797* & AB611798* & AB611799* \\
\hline $\begin{array}{l}\text { Gammatricula songi Davis, Chen \& } \\
\text { Yu, } 1994\end{array}$ & Aquatic & Genbank & - & EF394879 & EF394867 & EF394902 \\
\hline Lacunopsis sp. & Aquatic & Genbank & AF212910 & - & AF212897 & AF213343 \\
\hline Neotricula aperta (Temcharoen, 1971) & Aquatic & Genbank & AF531540 & AY207034 & AF531556 & AF531541 \\
\hline Neotricula burchi (Davis, 1968) & Aquatic & Genbank & AF531543 & AY207035 & AF531542 & AF531544 \\
\hline Robertsiella sp. & Aquatic & Genbank & AF531549 & - & AF531548 & AF531550 \\
\hline Tricula bollingi Davis, 1968 & Aquatic & Genbank & AF531552 & AY207039 & AF531551 & AF531553 \\
\hline Tricula fujianensis (Liu, et al., 1983) & Aquatic & Genbank & - & EF394885 & EF394873 & EF394893 \\
\hline Tricula hongshanensis Tang et al., & Aquatic & Genbank & - & EF394888 & EF394876 & EF394896 \\
\hline
\end{tabular}
1986 
Table 1 Sampling information of specimens used in the present study (Continued)

\begin{tabular}{|c|c|c|c|c|c|c|}
\hline Tricula hortensis Attwood et al., 2003 & Aquatic & Genbank & - & EF394883 & EF394871 & EF394900 \\
\hline Tricula hsiangi Kang, 1984 & Aquatic & Genbank & - & EF394889 & EF394877 & EF394897 \\
\hline Tricula pingi Kang, 1984 & Aquatic & Genbank & - & EF394881 & EF394869 & EF394901 \\
\hline Tricula wumingensis Hu et al., 1994 & Aquatic & Genbank & - & EF394884 & EF394872 & EF394892 \\
\hline \multicolumn{7}{|l|}{ ASSIMINEIDAE } \\
\hline $\begin{array}{l}\text { Angustassiminea satumana Habe, } \\
1942\end{array}$ & & Kikai Isl., Kagoshima & AB611800* & AB611801* & AB611802* & AB611803* \\
\hline Assiminea hiradoensis Habe, 1942 & & $\begin{array}{l}\text { Urakami, Nagasaki, } \\
\text { Nagasaki }\end{array}$ & AB611804* & AB611805* & AB611806* & AB611807* \\
\hline $\begin{array}{l}\text { Paludinellassiminea japonica (Pilsbry, } \\
\text { 1901) }\end{array}$ & & $\begin{array}{l}\text { Hiburi Isl., Uwajima, } \\
\text { Ehime }\end{array}$ & AB611808* & AB611809* & AB611810* & AB611811* \\
\hline Pseudomphala miyazakii (Habe, 1943) & & Ashikari, Ogi, Saga & AB611812* & AB611813* & AB611814* & AB611815* \\
\hline \multicolumn{7}{|l|}{ TRUNCATELLIDAE } \\
\hline Truncatella pfeifferi Martens, 1860 & & Nanao, Ishikawa & AB611816* & AB611817* & AB611818* & AB611819* \\
\hline \multicolumn{7}{|l|}{ AMNICOLIDAE } \\
\hline $\begin{array}{l}\text { Akiyoshia kobayashii Kuroda \& Habe, } \\
1958\end{array}$ & & Taga, Shiga & AB611820* & AB611821* & AB611822* & AB611823* \\
\hline \multicolumn{7}{|l|}{ LITTORINIDAE } \\
\hline $\begin{array}{l}\text { Echininus cumingi spinulosus (Philippi, } \\
\text { 1846) }\end{array}$ & & Kikai Isl., Kagoshima & AB611824* & AB611825* & AB611826* & AB611827* \\
\hline Littorina pallescens (Philippi, 1846) & & Nago, Okinawa & AB611828* & AB611829* & AB611830* & AB611831* \\
\hline
\end{tabular}

${ }^{1}$ Type locality

Taxon names, habitats, localities, and accession numbers are provided. Sequences obtained for this study are marked with an asterisk.

Oncomelania was sister to Triculinae. Following analysis using an approximately unbiased(AU) test [28], the monophyly of all pomatiopsine taxa was rejected $(P=$ 0.049), suggesting that Pomatiopsinae is paraphyletic to Triculinae.

Japanese pomatiopsine taxa were grouped into four lineages. Oncomelania and Cecina were both recovered as monophyletic, but two endemic genera, Fukuia and Blanfordia formed two clades, each of which included species from both genera (clades I and II; Figure 4). Clade I consisted of $F$. ooyagii and Blanfordia spp. except for $B$. integra, where $F$. ooyagii was sister to the Blanfordia species. Clade II was composed of B. integra, F. kurodai, and F. multistriata. These results indicate independent evolution of terrestriality in the two clades. Therefore, we tested the alternative hypothesis of the occurrence of terrestrial species. The monophyly of all Blanfordia species was rejected by approximately unbiased (AU) test $(P=0.000001)$, suggesting that land invasion occurred independently at least twice. In clade II, B. integra was placed between F. multistriata and F. kurodai. However, the detailed branching pattern and number of terrestrial invasions were uncertain within this clade because the monophyly of $B$. integra was not rejected (AU test, $P=0.07$ ).

\section{Estimation of divergence time}

To determine the timing of the origin of terrestriality in Pomatiopsidae, we estimated the divergence time based on the combined phylogeny of four genes. Fossil records and previous estimations were used to estimate the divergence time of pomatiopsid taxa. For the fossil records, Assiminea spp. from the Lower Miocene (23.0$16.0 \mathrm{Ma})[29,30]$ were used for the initial divergence of Assimineidae. The root node of "Truncatelloidea" (Truncatellidae + Pomatiopsidae + Assimineidae; sensu Ponder [31]) was modeled by a Gamma prior (shape $=1$ and scale $=1.5$ ) with values younger than $61.7 \mathrm{Ma}$ assigned zero probability, which is justified by Truncatella minor, the oldest known fossil for this group documented from the Lower Paleocene (65.5-61.7 Ma) of Belgium [32]. Based on these constraints, a basal split within Triculinae was inferred at $16.8 \mathrm{Ma}$ with a $95 \%$ confidence interval of 21.3-12.2 Ma (Figure 5A). The emergence of Japanese aquatic species $O$. minima and $F$. ooyagii were estimated at $16.0(21.2-10.6) \mathrm{Ma}$ and 17.4 (23.7-11.1) Ma, respectively. The terrestrial lineage in clade I began to diverge at $6.4(9.2-3.7) \mathrm{Ma}$. The diversification of clade II began at $7.2(10.3-4.4) \mathrm{Ma}$ and the terrestrial species $B$. integra occurred during the Pliocene.

We also estimated the divergence time by using the split between Oncomelania hupensis quadrasi and O. $h$. robertsoni, which was previously estimated at $3 \mathrm{Ma}$ based on allozyme differences [33]. Node ages calculated from this estimation were two to three times younger than former results. Thus, data from the two calibrations were not compatible at higher nodes (data not 


\section{A Clade I}

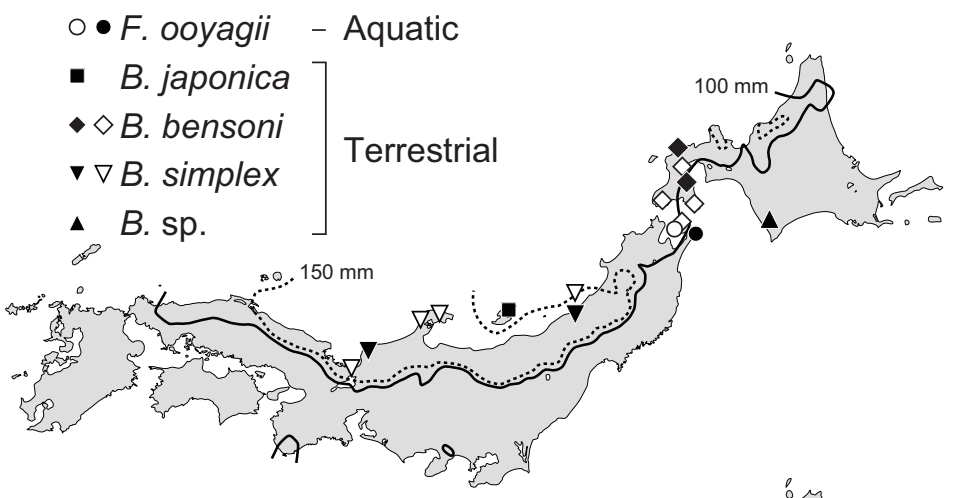

B Clade II (amphibious)

$\bullet$ F. kurodai

- $\square$ F. multistriata

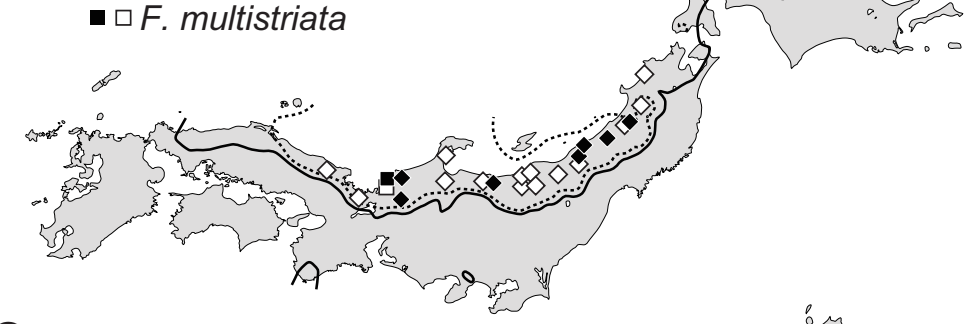

C Clade II (terrestrial)

- $\circ$ B. integra

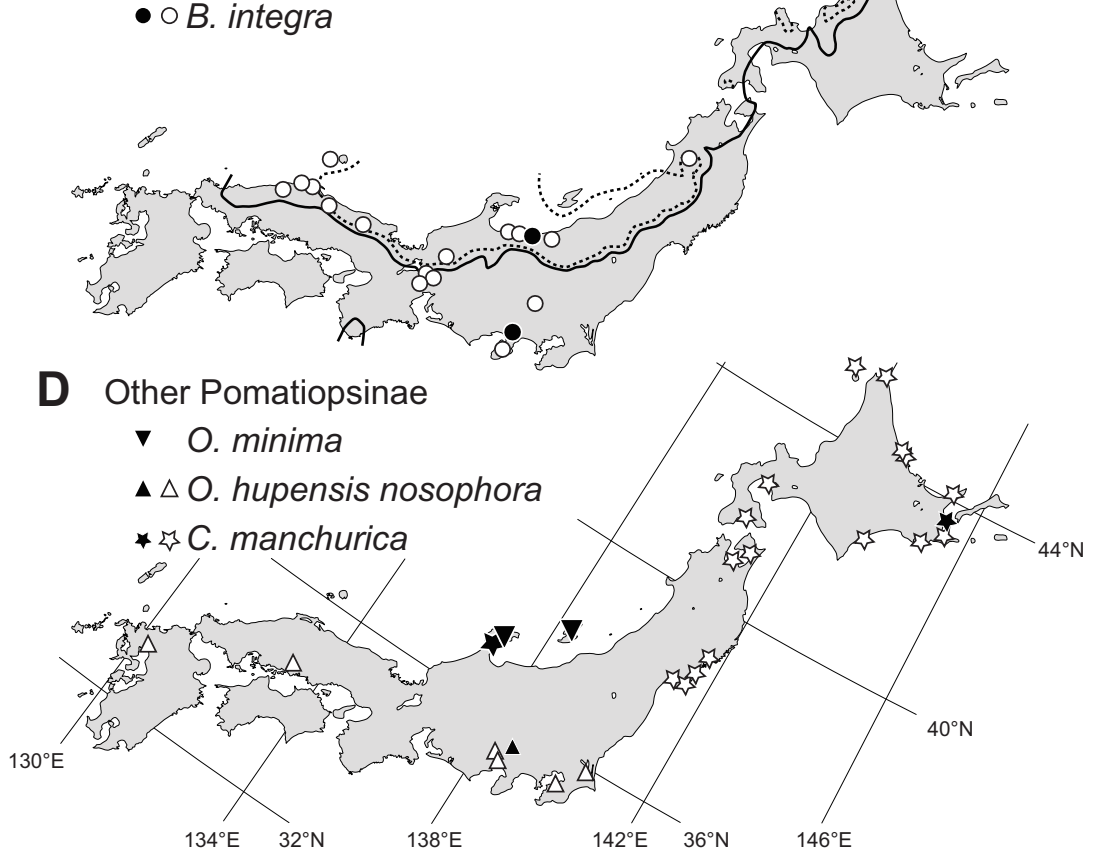

Figure 3 Maps of Japan showing distributions of Pomatiopsine taxa. (a) Clade 1; (b) amphibious species of clade 2, Fukuia kurodai and $F$. multistriata; (c) terrestrial species of clade 2, B. integra; (d) other pomatiopsine species. Solid and open symbols represent the collecting sites in this study and distribution record from the literature, respectively [22,35,72-76]. Solid and dashed curves indicate areas that have more than 100 $\mathrm{mm}$ and $150 \mathrm{~mm}$, respectively, of total precipitation in January (average of 1971-2000 [77]). 


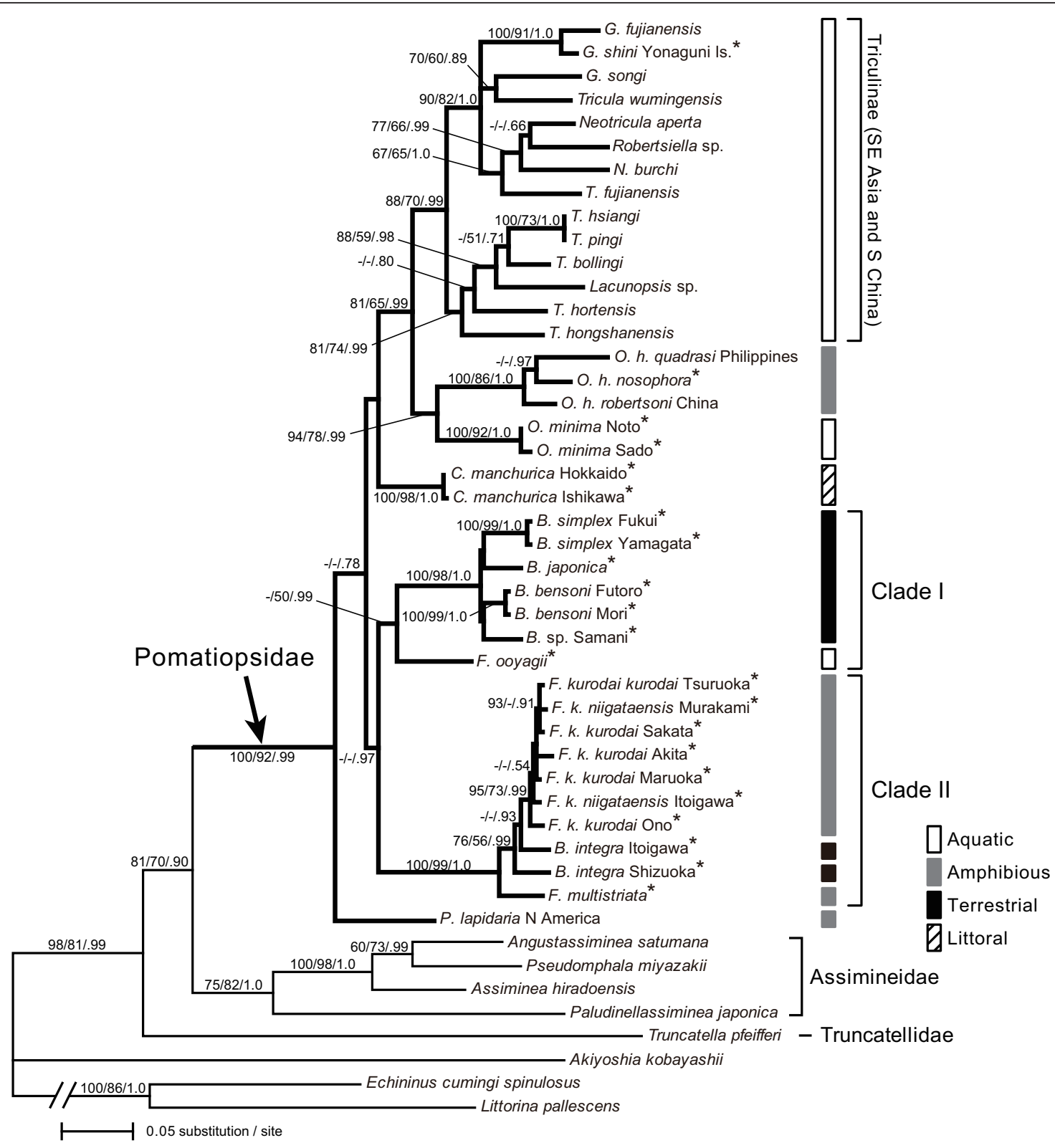

Figure 4 A maximum likelihood tree based on the combined dataset of 18S, 28S, 16S, and CO1 genes $(-$ In likelihood $=20667.0486)$ Numbers on branches indicate maximum parsimony and maximum likelihood bootstrap values followed by Bayesian posterior probabilities. Bars on the right of the tree indicate habitat of each taxon. Japanese pomatiopsid taxa are indicated by asterisks. Clades I and II are endemic to Japanese Archipelago.

shown). Although we could not determine which estimation is more accurate, we employed the former results because the node ages in the latter estimation were too young to explain the existence of fossils at earlier periods.

\section{Climatic factors contributing to distribution of endemic genera}

The two Japanese endemic lineages, clades I and II, are largely confined to the Japan Sea side of the Japanese
Archipelago (Figure 3). To determine whether this pattern is associated with any climate factors, we performed logistic regression analysis based on four variables, i.e., annual highest and lowest temperatures, and total precipitations in summer and winter. The logistic regression analysis showed significant correlation between winter precipitation and the occurrence of the snails, whereas contributions of the other variables were not significant (Table 2). Although we did not include the amount of snowfall due to the significant correlation with winter 
precipitation (Spearman's rank correlation coefficient, $p$ $=0.0054)$, its difference was also significant between inside and outside of the distributions (Wilcoxon's signed-rank test, $z=-3.009, p=0.0026$ ).

\section{Discussion}

\section{Phylogenetic and taxonomic implications}

The phylogenetic analyses supported the monophyly of Triculinae. On the other hand, Pomatiopsinae was paraphyletic to the former subfamily, and an Asian genus Oncomelania became sister to Triculinae (Figure 4). These results suggest that taxonomy and phylogeographic scenarios should be reconsidered. Traditionally, Pomatiopsidae is considered to have diverged into two subfamilies in Gondwanaland during the Mesozoic, mainly because three pomatiopsine genera shows Gondwanan distribution (Coxiella, Idiopyrgus and Tomichia; Figure 1) [11]. However, the close relationship between Triculinae and Oncomelania and the estimated divergence time suggest that Triculinae have evolved more recently on the Eurasian Continent, not in Gondwanaland. Although we could not provide alternative scenarios from current phylogenetic results, further study, including remaining pomatiopsine genera, is needed to reconsider subfamilial taxonomy and worldwide phylogeography of this family.

Incongruence between current taxonomy and molecular phylogeny was also observed on Japanese endemic genera Fukuia and Blanfordia. The terrestrial species $B$. integra was grouped with the amphibious species $F$. kurodai and F. multistriata, whereas aquatic species $F$. ooyagii was separated from the other Fukuia species (Figure 4). Our results indicated the inadequacy of the current taxonomy of the two genera, which have been primarily based on their habitat [34]. In contrast, internal morphologies likely reflect the phylogenetic relationship. Davis [11] noted that genital structures of $B$. integra are similar to those of Fukuia. Although he doubted if Fukuia and Blanfordia are morphologically distinct based on such evidence, it is an apparent confusion resulting from the inadequate generic assignment of $B$. integra, for genital and nervous structures clearly differ between species in clade I and II $[11,21]$. Snails in clade II also commonly climb up grasses and shrubs during summer (Figure 2K) [11, 35, Y. Kameda, pers. obs.]. This behavior characterizes clade II, since treeclimbing behavior is known only in these snails and a few arboreal species of the assimineid genus Omphalotropis throughout the superfamily [36]. Hence, B. integra is undoubtedly a member of the genus Fukuia. At the same time, F. ooyagii should be separated from Fukuia, and its generic assignment should be determined coupled with the investigation of its soft-part morphology.
Divergence time and patterns of Japanese Pomatiopsinae The number of inhabiting pomatiopsine genera is particularly high in the Japanese Archipelago (Figure 1). Davis [11] considered that the diversity of Japanese Pomatiopsinae results from the single colonization and following radiation of ancestral Oncomelania in the archipelago, and that such rapid evolution presumably associated with extensive tectonic activity in the Tertiary. However, our phylogenetic analysis grouped Japanese pomatiopsine snails into four lineages, Oncomelania, Cecina, and clades I and II (Figure 4). These results contradict the scenario of Davis [11], suggesting that current diversity is partially derived from the multiple colonization of pomatiopsine ancestors into the Japanese Archipelago. Subsequent habitat shifts may have contributed to increasing diversity and produced the terrestrial lineages.

The widespread genus Oncomelania comprises two Japanese taxa, O. minima and O. h. nosophora (Figures 2Q \&2R). These two taxa are not closely related, suggesting that colonization to the Japanese Archipelago occurred twice in this genus. The age of divergence between O. minima and O. hupensis was estimated around 16.0 Ma in the Middle Miocene (Figure 5A), suggesting that this divergence was likely invoked by the expansion of the Japan Sea, which is thought to have occurred during this period $[37,38]$. O. h. nosophora diverged from other continental subspecies more recently and likely colonized into Japan during glacial periods in the Late Pleistocene [39].

The littoral genus Cecina also occurs in the Japanese Archipelago. This genus consists of a single widespread species, Cecina manchurica, living among the decaying seaweed stranded on the seashore (Figures 2G \&2S) [11]. Although we could not elucidate the divergence time of this genus due to low support values, the wide distribution was formed by recent dispersions via ocean currents based on very low genetic diversity between geographically distant populations (Figures 3D \&4).

The divergence between two Japanese endemic lineages, clades I and II, was estimated to be around 21.7 $\mathrm{Ma}$ in the Early Miocene (Figure 5A). This period corresponds to incipient opening of the Japan Sea, and the northern and southern parts of the Japanese Archipelago that were separated from each other $[37,38,40]$. This geological event might have also split the two clades (Figure 5B). The northern part of the Japanese Archipelago was further fragmented at later periods until the orogenesis of the northeastern Japanese Archipelago began in the later Late Miocene $[37,41]$. Speciation in clade I may be explained by geographic isolation due to this geological event, and the narrow distribution of each species may reflect the past geographic isolation (Figures 3A \&5C). Remarkably, B. simplex is widely 

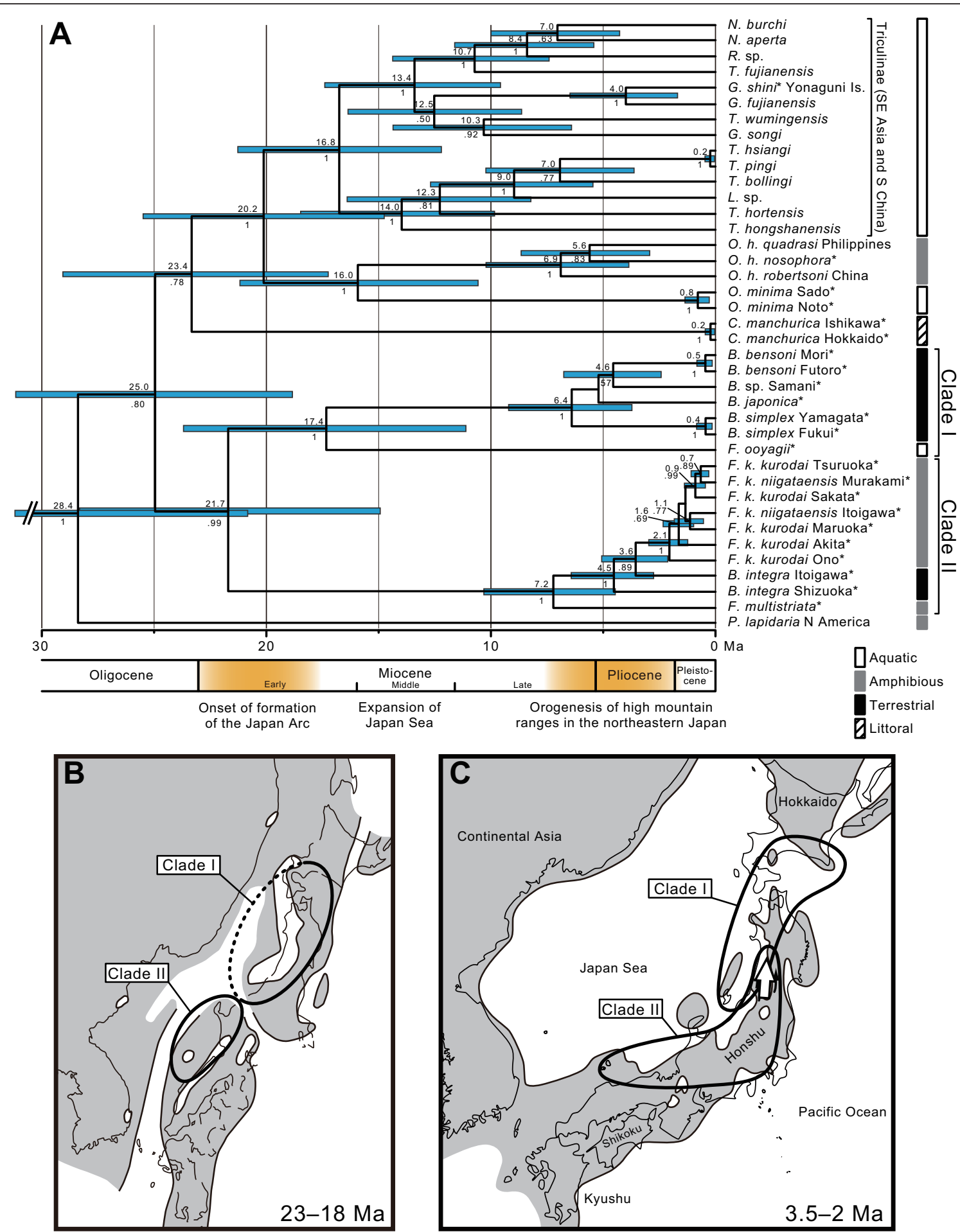

Figure 5 Maximum clade probability tree displayed as a chronogram and paleogeography around the Japanese Archipelago. (A) Divergence times calculated in BEAST based on fossil records (outgroups not shown). Japanese pomatiopsid taxa are indicated by asterisks. Horizontal bars in the tree give the $95 \%$ credible interval for the age of each node. Numbers above and below branches represent mean node ages and posterior probabilities, respectively. (B, C) Hypothesized paleodistribution of clades I and II. Paleogeographic maps of East Asia were modified from lijima \& Tada [37]. Shaded areas indicate land. (B) Early Miocene (23-18 Ma), divergence of two clades. (C) Middle to late Pliocene (3.5-2 Ma), ongoing diversification and range expansion within each clade. 
Table 2 Chi-square statistics from the logistic regression analysis

\begin{tabular}{lll}
\hline Variables & $\boldsymbol{\chi}^{\mathbf{2}}$ & $\mathbf{P}$ \\
\hline Highest temperature & $1.6651 \times 10^{-9}$ & 1 \\
Lowest temperature & $9.7577 \times 10^{-7}$ & 0.9992 \\
Summer precipitation & $2.9000 \times 10^{-8}$ & 0.9999 \\
Winter precipitation & 34.7674 & $<0.0001$ \\
\hline
\end{tabular}

Degrees of freedom was 1 for all variables.

distributed along the Japan Sea and occurs on coastal dunes as well as littoral forests, whereas the other species inhabit rather inland forests [22,42]. The low genetic differentiation and habitat of $B$. simplex suggest that a geological barrier has been absent for the coastal species.

The southern part of the Japanese Archipelago, where clade II was thought to have inhabited (Figure 5B), remained as a relatively large landmass. The land area had expanded northward in the Late Miocene along with the beginning of orogenesis in the northeastern part of the archipelago [37,38]. The diversification of clade II likely started in the Late Miocene (around 7.2 $\mathrm{Ma}$; Figure 5A), indicating that tectonic activities might have enabled the range expansion of clade II to northeastern Honshu (Figure 5C).

\section{Routes of terrestrial invasion}

The terrestrial pomatiopsid species are found in clades I and II (Figure 4). The snails in both clades are largely restricted to mountains in the Japan Sea side of the Japanese Archipelago (Table 1; Figures 3A-C), where winter precipitations are especially high among the distributions of pomatiopsine genera (Figure 6). Because winter precipitation falls as snow in this region, terrestrial invasion may have occurred via mountain streamlets that are covered with heavy snowfall in winter. This evolutionary hypothesis contrasts with the current knowledge of terrestrial invasion in two points. First, evolution of terrestriality most likely occurred via mountain streamlets. Generally, that animals would evolve terrestriality near rivers and streams than in lakes and swamps seems less likely due to adaptations for air breathing, particularly in the latter environment with its frequent reductions in dissolved oxygen [3]. Second, terrestrial invasion likely occurred in a cool-temperate region. Colonization to land is considered to have occurred primarily in the tropics during mild climate periods $[3,4]$. To our knowledge, this is the first case in which terrestriality might have evolved in a cool region. Therefore, the questions on how terrestriality was acquired beside the streamlets and which climatic factors enabled this evolution under such cold climates remain to be elucidated.

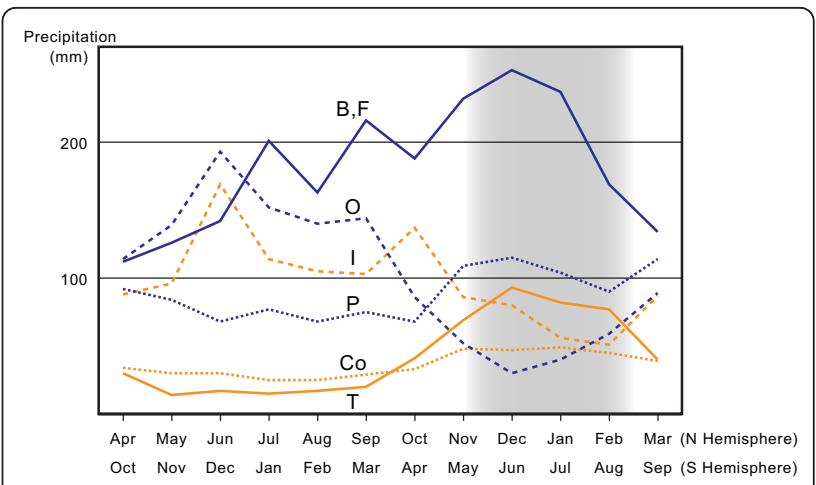

Figure 6 Monthly precipitations in the distributions of pomatiopsine genera. Values for each genus, except for Idiopyrgus and Tomichia, are average of 5 localities which was randomly selected from the distribution. The precipitation data were obtained from the World Meteorological Organization (WMO; http://www. wmo.int/). Blue and orange lines represent genera in Northern and Southern Hemisphere, respectively. Distribution of Fukuia and Blanfordia has especially high precipitation during winter (shaded period). B, Blanfordia; Co, Coxiella; F, Fukuia; I, Idiopyrgus; O, Oncomelania; P, Pomatiopsis; T, Tomichia.

The aquatic and amphibious species of clades I and II, which likely represent ancestral habitats of terrestrial taxa, inhabit mountain streamlets and rocky walls that are constantly moistened by dripping water and covered with ferns and bryophytes (Figure 2) [21,22]. When these habitats become drier, both amphibious and aquatic species are able to resist the short-term drying by crawling into crevices and wet litter [21]. Correlation between desiccation tolerance and wetness of habitat is observed in some animals $[11,43,44]$; thus, frequent droughts may have promoted the ancestral freshwater snails to the more amphibious lifestyle beside the mountain streamlets. Amphibious snails in some populations can actively move onto terrestrial substrata and mate outside the water (Figure 2I). Therefore, the colonization to terrestrial habitats was presumably achieved by becoming more tolerant to desiccation. The availability of dissolved oxygen might not have influenced the habitat shifts of these snails because their ancestors may have preadapted to amphibious habitats [11,12].

The snails in clades I and II mainly occur on the Japan Sea side of the Japanese Archipelago (Figure 3), whose climate is unique in East Asia. This area is generally dominated by a monsoon climate, characterized by alternating hot rainy summers and cold dry winters [23]. However, the Japan Sea side of the archipelago has exceptionally high winter precipitation due to the winter monsoon blowing southward from the Japan Sea and the high mountain ranges that bring enormous snowfall $[24,25,45]$. This region harbors various unique flora and fauna that are known as "Japan Sea elements" [26,27], whose distributions clearly correspond to the amount of 
snowfall [46-48]. These organisms are not always resistant to the stress of winter coldness and desiccation, and often need snow coverage under which stable temperatures around $0^{\circ} \mathrm{C}$ and high humidity are maintained [49-54]. Snails of clades I and II are also considered as Japan Sea elements $[22,35]$. The logistic regression analysis showed significant correlation between winter precipitation and occurrence of the snails (Table 2), suggesting a high degree of need for high winter precipitation, which brings snow coverage, to ensure their survival.

Heavy-snow environments in the Japanese Archipelago were established by the formation of Japan Sea and high mountain ranges in the archipelago $[55,56]$. The orogenesis of the northern Honshu occurred since the late Miocene $[37,38,41]$, whose period corresponds to the diversification and terrestrial invasion of Japanese endemic clades (Figure 5A). According to the vegetation in the late Miocene to Pliocene, northern Honshu was cool-temperate and later became colder [57,58]. The amount of snowfall increased with the growth of high mountain ranges during the Pleistocene [56]. Although the amount of snowfall during these periods is uncertain, arid or semi-arid climates did not appear in this region $[24,56]$, suggesting the presence of constantly moist environments that were suitable for the survival of snails in clades I and II. Therefore, the establishment of snowy regions may have paved the way for these organisms from freshwater to land via mountain streamlets by preventing winter desiccation in mountain valleys.

The fact that terrestrial invasion in Pomatiopsidae did not occur except in the snowy region provides an indication of molluscan terrestrialization. Many pomatiopsid snails lived in the floodplains of continental Asia [11], where the dry and wet seasonal cycle is dominant (Figure 6). However, such climate seems insufficient to lead the seasonal amphibious snails to terrestrial habits. In contrast, year-round wet environments were most likely necessary for amphibious snails to become terrestrial, contrary to the belief that seasonal drought accelerates terrestrial invasion [3]. The terrestrial lineages, especially in clade II, have specific behaviors when crawling up vegetation $[11,35]$. Ancestral amphibious lineages in water films found on wet rocky walls would have enabled the preadaptation of this type of behavior accompanied by a broad, strong foot.

\section{Conclusions}

The generic and ecological diversity of Pomatiopsinae is particularly high in the Japanese Archipelago, with its terrestrial taxa occurring only in this region. Our phylogenetic analyses suggested that the Japanese Pomatiopsinae derived from the multiple colonization from the Eurasian
Continent and subsequent habitat shift to the terrestrial life occurred at least twice within the Japanese endemic lineages (clades I and II; Figure 4). The evolution of terrestriality possibly occurred beside mountain streamlets of snowy regions, where snow coverage shelters the ground surface from winter desiccation and coldness $[51,54]$. The estimated divergence time also suggested that diversification of the endemic clades began in the Late Miocene, which is the period corresponding to the orogenesis of the Japanese Archipelago and expansion of the Japan Sea (Figure 5). The emergence of the heavysnow region is associated with these tectonic activities [56]; therefore, the terrestrial invasion of pomatiopsid snails may have been promoted by the formation of the archipelago and the establishment of snowy conditions that led the way from freshwater to land via mountain streamlets. The fact that terrestrial invasions of Pomatiopsidae occurred only in year-round wet and cool environments, but not in seasonally dried regions, gives new insight into molluscan terrestrialization.

\section{Methods \\ Sampling}

To investigate the evolutionary history of Japanese pomatiopsids, we collected 13 taxa from 23 localities to represent all Japanese pomatiopsids. The sequence data of non-Japanese pomatiopsids were obtained from GenBank, but species that lack two or more examined gene regions were excluded from the phylogenetic analysis. As a result, 13 triculine species and 3 non-Japanese pomatiopsine taxa were included in the analysis, although they do not encompass representatives of all pomatiopsine genera. However, it would not matter in discussing the evolution within Japanese taxa because excluded pomatiopsine genera are unlikely related to our focusing taxa based on genital structures [11]. For outgroups, we used four assimineids, one truncatellid, one amnicolid, and two littorinids. Detailed information on examined samples is shown in Table 1.

\section{Molecular methods}

Total DNA was isolated following a previously described method [59]. We sequenced the partial region of the nuclear $18 \mathrm{~S}$ rDNA and 28S rDNA, mitochondrial cytochrome oxidase subunit 1 (CO1), and 16S rDNA. Polymerase chain reaction (PCR) conditions and primers used are shown in Additional File 1. PCR products were purified using Exo-SAP-IT (Amersham Biosciences, Little Chalfont, Buckinghamshire, UK). Sequencing was performed using a BigDye ${ }^{\mathrm{TM}}$ Terminator Cycle Sequencing Ready Reaction Kit (Applied Biosystems, Foster City, CA) and electrophoresed on an ABI 3130 sequencer (Applied Biosystems). The obtained sequences were deposited in the DNA Data Bank of Japan (DDBJ) (Table 1). 


\section{Phylogenetic analyses}

The alignment of the CO1 gene required no gaps; $16 \mathrm{~S}$, $18 \mathrm{~S}$, and $28 \mathrm{~S}$ sequences were aligned using MUSCLE v3.8 [60]. To eliminate the uncertainty of the alignments in these gene regions, GBLOCKS v0.91b [61] was used to select those regions of the aligned sequences that are confidently aligned for analysis (Additional File 2). Phylogenetic trees were obtained by maximum parsimony (MP), maximum likelihood (ML), and Bayesian methods. MP analysis was performed using PAUP* 4.0b10 [62] and heuristic searches were conducted with 10 random addition analyses using equal character weights and tree-bisection-reconnection (TBR) branch swapping. Prior to ML and Bayesian analyses, we used the program Kakusan3 v3.5.2009.11.03 [63] to select appropriate models of sequence evolution (Additional File 2). Based on the selected models, ML analysis was performed with 1000 iterations of the likelihood ratchet $[64,65]$ using TreeFinder [66] and Phylogears version 1.5.2009.12.29 [67]. Nodal support for the MP and ML analyses was assessed using bootstrap analyses with 1000 replications. Bayesian analysis was performed using MrBayes v3.1.2 [68,69]. The analysis was carried out by two simultaneous runs, each of which consisted of running four simultaneous chains for 10 million generations and sampling trees every 1000 generations. We discarded the first 1001 trees as burn-in and the remaining 18000 samples were used to estimate the tree topology, branch length, and substitution parameters. The alignments and obtained trees were deposited in TreeBASE http://www.treebase.org/treebase-web/home.html under accession number S11213.

\section{Approximately unbiased (AU) test}

Given that the phylogenetic analyses indicated that the terrestrial genus Blanfordia and aquatic/amphibious genus Fukuia formed mixed clades (see Results), we performed the AU tests [28] to test an alternative hypothesis for the evolution of terrestrial species. The alternative trees were obtained by the likelihood ratchet method as described above under the topological constraint that all Blanfordia species were monophyletic (i. e., terrestrial invasion occurred once) and that $B$. integra was monophyletic, indicating that terrestriality evolved at least twice. In addition, the AU test was also performed to test the monophyly of Pomatiopsinae, because it was not recovered as monophyletic and because support values among pomatiopsine genera were low. The AU test was conducted based on 1 million replications using TreeFinder.

\section{Estimation of divergence time}

Approximate divergence times were estimated using a relaxed clock method [70] as implemented in BEAST
1.5.3 [71]. Divergence times were calculated using previous estimations and fossil records. We first used the split between Oncomelania hupensis quadrasi and $O$. $h$. robertsoni, which was previously estimated at 3 Ma based on allozyme differences [33]. For the fossil records, three fossils were used to place priors on node ages. A normally distributed estimate prior of $19.5 \pm 3.5 \mathrm{Ma}$ was used for the basal divergence of Assimineidae, based on Assiminea from the Lower Miocene (23.0-16.0 Ma) of Florida, USA [29] and the Marshall Islands [30]. The basal splitting of "Truncatelloidea" (Truncatellidae + Assimineidae + Pomatiopsidae; sensu Ponder [31]) was modeled by a Gamma prior (shape $=1$ and scale $=1.5$ ) with values younger than $61.7 \mathrm{Ma}$ assigned zero probability, which is justified by Truncatella minor, the oldest known fossil for this group documented from the Lower Paleocene (65.5-61.7 Ma) of Belgium [32]. Divergence times for the remaining nodes in the phylogenetic tree were estimated with BEAST software. The Yule process was used to model the speciation process. The Monte Carlo Markov chain was run eight times for 10 million generations sampled every 1000 generations to ensure that the effective sample size (ESS) values were above 200 for most of the parameters. The first 1001 trees of each run were discarded as burn-in and the remaining trees were combined to produce an ultrametric consensus tree using LogCombiner and TreeAnnotator v1.5.3 (included in the BEAST software package).

\section{Climatic factors contributing to distribution of endemic genera}

The two Japanese endemic genera, Fukuia and Blanfordia, are largely confined to the Japan Sea side of the Japanese Archipelago, i.e., heavy-snow regions (Figure 3). The distributions of these genera seem to be restricted by the amount of snowfall, but other climatic factors may have affected the survival of these snails. Therefore we performed logistic regression analysis to investigate the association between climatic factors and the occurrence of these snails. We used annual highest and lowest temperatures, and total precipitations in summer (between June and August) and winter (between December and February) as climatic factors. The climatic data were obtained from the Japan Meteorological Agency http://www.jma.go.jp. Within the distribution of Fukuia and Blanfordia, 14 localities were selected to cover the entire range of these genera (Additional file 3). For the localities outside the distributions, we selected 11 weather stations, each of which is nearest to an inside-distribution locality across the high mountain ranges and has similar altitude. 


\section{Additional material}

\section{Additional file 1: Information on primers and PCR conditions used in this study.}

Additional file 2: Information on sequence alignments and models of sequence evolution for maximum likelihood analysis.

Additional file 3: Information on localities used for the investigation of climatic factors.

\section{Acknowledgements}

We thank H. Fukuda, T. Haga, Y. Nakase and R. Tsubaki for sample collection; Y. Imada for data analysis; and H. Fukuda and A. Kawakita for helpful suggestions on our manuscript. This work was partially supported by JSPS Research Fellowships for Young Scientists No. 20-3560.

\section{Authors' contributions}

YK designed the study, collected material, carried out gene sequencing, performed phylogenetic analyses, and drafted the manuscript. MK conceived of the study, participated in its design, collected material and helped to draft the manuscript. All authors have read and approved the final manuscript.

Received: 21 September 2010 Accepted: 5 May 2011

Published: 5 May 2011

\section{References}

1. Shear WA: The early development of terrestrial ecosystems. Nature 1991, 351:283-289.

2. Vermeij GJ, Dudley R: Why are there so few evolutionary transitions between aquatic and terrestrial ecosystems? Biol J Linn Soc 2000, 70:541-554.

3. Little C: The terrestrial invasion. An ecophysiological approach to the origin of land animals Cambridge: Cambridge University Press; 1990.

4. Little C: The colonisation of land: Origins and adaptations of terrestrial animals Cambridge: Cambridge University Press; 1983.

5. Wenz W: Gastropoda extramarina tertiaria. Nos. 4, 6. In Fossilium Catalogus 1: Animalia pt. 23. Edited by: Pompeckj JF. Berlin: Junk; 1923:1069-1420, 1735-1862

6. Rosenberg G: Independent evolution of terrestriality in Atlantic truncatellid gastropods. Evolution 1996, 50:682-693.

7. Zilch A: Gastropoda, pt. 2, Euthyneura Berlin: Borntraeger; 1959-1960.

8. Baker GM: Gastropods on land: phylogeny, diversity, and adaptive morphology. In The Biology of Terrestrial Molluscs. Edited by: Baker GM. New Zealand: CABI Publishing; 2001:1-146.

9. Kano $Y$, Chiba $S$, Kase T: Major adaptive radiation in neritopsine gastropods estimated from $28 \mathrm{~S}$ rRNA sequences and fossil records. Proc $R$ Soc Lond B 2002, 269:2457-2465.

10. Solem A: Biogeographic significance of land snails, Paleozoic to Recent In Historical Biogeography, plate tectonics, and the changing environment. Edited by: Gray J, Boucot AJ. Oregon: Oregon State University Press; 1979:277-287.

11. Davis GM: The origin and evolution of the gastropod family Pomatiopsidae, with emphasis on the Mekong river Triculinae. Monogr Acad Nat Sci Phila 1979, 20:1-120.

12. Davis GM: Historical and ecological factors in the evolution, adaptive radiation, and biogeography of freshwater mollusks. Am Zool 1982, 22:375-395.

13. Dillon RT Jr: The Ecology of Freshwater Molluscs Cambridge: Cambridge University Press; 2000.

14. Bartsch P: Molluscan intermediate hosts of the Asiatic blood fluke, Schistosoma japonicum, and species confused with them. Smithson Misc Collect 1936, 95:1-60

15. Davis GM: Snail hosts of Asian Schistosoma infecting man: evolution and coevolution. Malacol Rev Suppl 1980, 2:195-238.

16. Rollinson D, Southgate VR: The genus Schistosoma: a taxonomic appraisal. In The biology of schistosomes: from genes to latrines. Edited by: Rollinson D, Simpson AJG. London: Academic Press; 1987:1-49.
17. Attwood SW: Scistosomiasis in the Mekong region: epidemiology and phylogeography. Adv Parasitol 2001, 50:87-152.

18. Blair D, Davis GM, Wu B: Evolutionary relationships between trematodes and snails emphasizing schistosomes and paragonimids. Parasitology 2001, 123:S229-S243.

19. Attwood SW, Ambu S, Meng XH, Upatham ES, Xu FS, Southgate VR: The phylogenetics of triculine snails (Rissooidea: Pomatiopsidae) from Southeast Asia and southern China: Historical biogeography and the transmission of human schistosomiasis. J Molluscan Stud 2003, 69:263-271.

20. Williams WD, Mellor MW: Ecology of Coxiella (Mollusca, Gastropoda, Prosobranchia), a snail endemic to Australian salt lakes. Palaeogeogr Palaeoclimatol Palaeoecol 1991, 84:339-355

21. Abbott RT, Hunter GW III: Studies on potential snail hosts of Schistosoma japonicum. Proc Helminthol Soc 1949, 16:73-89.

22. Minato H: Blanfordia japonica group (Gastropoda: Pomatiopsidae) considered as the distributional pattern of the so-called "Japan Sea element" confined to the Japan Sea region. Nanki Seibutu 1987, 29:21-24.

23. Webster PJ, Magana VO, Palmer TN, Shukla J, Tomas RA, Yanai M, Yasunari T: Monsoons: processes, predictability, and the prospects for prediction, in the TOGA decade. J Geophys Res 1998, 103:14451-14510.

24. Suzuki H: The classification ofJapanese climates. Tirigaku Hyouron 1962, 35:205-211.

25. Ninomiya K: Heat and water budget over the Japan Sea and the Japan Island in winter season. J Meteor Soc Jpn 1968, 46:343-372.

26. Fukuoka N: On the distribution patterns of the so-called Japan Sea elements confined to the Sea of Japan region. J Geobotany 1966, 15:63-80.

27. Hotta M: History and Geography of Plants. Evolutionary Biology in Plants III Tokyo: Sanseido; 1974.

28. Shimodaira $\mathrm{H}$ : An approximately unbiased test of phylogenetic tree selection. Syst Biol 2002, 51:492-508.

29. Mansfield WC: Molluscs of the Tampa and Suwannee limestones. Geol Bull No 15, State Fla Dep Conserv 1937, 15:1-334

30. Ladd HS: Chitons and Gastropods (Haliotidae through Adeorbidae) from Western Pacific Islands. US Geol Surv Professional Pap 1966, 531:1-98.

31. Ponder WF: The truncatelloidean (= rissoacean) radiation - a preliminary phylogeny. In Prosobranc Phylogeny. Malacological Review, Supplement 4 Edited by: Ponder WF 1988, 129-166.

32. Glibert M: Revision des Gastropoda du Danien et du Montien de la Belgique. I, Les Gastropoda du Calcaire de Mons. Inst R Sci Nat Belg Mem 1973, 173:1-115.

33. Woodruff DS, Staub KC, Upatham ES, Viyanant V, Yuan H: Genetic variation in Oncomelania hupensis: Schistosoma japonicum transmitting snails in China and the Philippines are distinct species. Malacologia 1988, 29:347-361.

34. Minato H: Pomatiopsidae. In Illustrations of Animals and Plants 8. Mollusca. Edited by: Okutani T. Tokyo Sekaibunka-sya; 1986:72-73.

35. Minato H: Blanfordia integra Pilsbry, 1924 (Pomatiopsidae); its morphology, ecology, and distribution. Nanki Seibutu 1980, 22:77-79.

36. Florens FBV, Baider C: Relocation of Omphalotropis plicosa (Pfeiffer, 1852), a Mauritian endemic landsnail believed extinct. J Molluscan Stud 2007, 73:205-206.

37. lijima A, Tada R: Evolution of Tertiary sedimentary basins of Japan in reference to opening of the Japan Sea. J Fac Sci, Univ Tokyo, Sec II 1990, 22:121-171.

38. Yonekura N, Kaizuka S, Nogami M, Chinzei K, (Eds): In Regional Geomorphology of the Japanese Islands. Introduction to Japanese Geomorphology. Volume 1. Tokyo: University of Tokyo Press; 2001.

39. Okamoto M, Lo CT, Tiu WU, Qui D, Hadidjaja P, Upatham S, Sugiyama H, Taguchi T, Hirai H, Saitoh Y, Habe S, Kawanaka M, Hirata M, Agatsuma T: Phylogenetic relationships of snails of the genera Oncomelania and Tricula inferred from the mitochondrial 12S rRNA gene. Jpn J Trop Med Hyg 2003, 31:5-10.

40. Maruyama S, Isozaki Y, Kimura G, Terabayashi M: Paleogeographic map of the Japanese Islands: Plate tectonic synthesis from 750Ma to the present. The Island Arc 1997, 6:121-142.

41. Koike K, Tamura T, Chinzei K, Miyagi T, (Eds): In Regional geomorphology of the Japanese Islands. Geomorphology of Tohoku Region. Volume 3. Tokyo: University of Tokyo Press; 2005.

42. Ekawa K: A note on Blanfordia japonica from Fukui Prefecture. Chiribotan 1985, 15:93-97. 
43. Houck MA, Bellis ED: Comparative tolerance to desiccation in the salamanders Desmognathus $f$. fuscus and Desmognathus o. ochrophaeus. J Herpetol 1972, 6:209-215.

44. Camp CD, Huestis DL, Marshall JL: Terrestrial versus aquatic phenotypes correlate with hydrological predictability of habitats in a semiterrestrial salamander (Urodela, Plethodontidae). Biol J Linn Soc 2007, 91:227-238.

45. Japan Meteorological Agency: Climataic atlas of Japan Tokyo: Japan Meteorological Agency; 2001.

46. Yamazaki T: The plants distribution of Japan. Shizenkagaku to Hakubutsukan 1959, 26:1-19.

47. Uemura S, Takeda T, Nakanishi N: Behaviours of the main temperate plants in Hokkaido along climatic gradients. Jpn J Ecol 1986, 36:141-152.

48. Shimano K: Regeneration dynamics, causal factors, and characteristics of Pacific Ocean-type beech (Fagus crenata) forests in Japan: a review. Folia Geobot 2002, 37:275-296.

49. Bliss LC: Adaptations of arctic and alpine plants to environmental conditions. Arctic 1962, 15:117-144.

50. Sakai A, Hakoda N: Cold hardiness of the genus Camellia. J Am Soc Hortic Sci 1979, 104:53-57.

51. Yoshino MM: Natural regions of Japan. GeoJournal 1980, 4:161-172

52. Sakai A, Larcher W: Frost Survival of Plants: Responses and Adaptation to Freezing Stress Berlin: Springer-Verlag; 1987.

53. Kume A, Ino Y: Comparison of ecophysiological responses to heavy snow in two varieties of Aucuba japonica with different distributing areas. Ecol Res 1993, 8:111-121.

54. Kume A, Tanaka C: Adaptation of stomatal response of Camellia rusticana to a heavy snowfall environment: Winter drought and net photosynthesis. Ecol Res 1996, 11:207-216.

55. Suzuki H: Uber die Bereiche des winterlichen Niederschlags in Japan. Tirigaku Hyouron 1961, 34:321-326.

56. Kaizuka S: Late Cenozoic palaeogeography of Japan. GeoJournal 1980, 4:101-109.

57. Tanai T: Tertiary history of vegetation in Japan. In Floristics and paleofloristics of Asia and North America. Edited by: Graham A. Amsterdam: Elsevier; 1972:231-255.

58. Maekawa F: Origin and characteristics of Japan's flora. In The Flora and Vegetation of Japan. Edited by: Numata M. Tokyo-Amsterdam: KodanshaElsevier; 1974:33-86.

59. Kameda Y, Kawakita A, Kato M: Cryptic genetic divergence and associated morphological differentiation in the arboreal land snail Satsuma (Luchuhadra) largillierti (Camaenidae) endemic to the Ryukyu Archipelago, Japan. Mol Phylogenet Evol 2007, 45:519-533.

60. Edgar RC: MUSCLE: multiple sequence alignment with high accuracy and high throughput. Nucleic Acids Res 2004, 32:1792-1797.

61. Castresana J: Selection of conserved blocks from multiple alignments for their use in phylogenetic analysis. Mol Biol Evol 2000, 17:540-552.

62. Swofford DL: PAUP*. Phylogenetic analysis using parsimony ( ${ }^{*}$ and other methods). Version 4.0 Sunderland, MA: Sinauer Associates; 2002.

63. Tanabe AS: Kakusan: a computer program to automate the selection of a nucleotide substitution model and the configuration of a mixed model on multilocus data. Mol Ecol Notes 2007, 7:962-964.

64. Nixon KC: The parsimony ratchet: a new method for rapid parsimony analysis. Cladistics 1999, 15:407-414.

65. Vos RA: Accelerated likelihood surface exploration: the likelihood ratchet. Syst Biol 2003, 52:368-373.

66. Jobb G: TREEFINDER. version of October 2008 Munich, Germany; 2008 [http://www.treefinder.de], Distributed by the author at.

67. Tanabe AS: Phylogears version 1.5.2009.12.29, software distributed by the author 2008 [http://www.fifthdimension.jp/].

68. Huelsenbeck JP, Ronquist F: MRBAYES: Bayesian inference of phylogenetic trees. Bioinformatics (Oxf) 2001, 17:754-755.

69. Ronquist $F$, Huelsenbeck JP: MRBAYES 3: Bayesian phylogenetic inference under mixed models. Bioinformatics (Oxf) 2003, 19:1572-1574.

70. Drummond AJ, Ho SYW, Phillips MJ, Rambaut A: Relaxed phylogenetics and dating with confidence. PLOS Biol 2006, 4:e88.

71. Drummond AJ, Rambaut A: BEAST: Bayesian evolutionary analysis by sampling trees. BMC Evol Biol 2007, 7:214

72. Minato H: Blanfordia integra. In Threatened Wildlife of Japan: Red Data Book 2nd ed., Land and Freshwater Mollusks. Volume 6. Edited by: Ministry of the Environment. Tokyo: Ministry of the Environment; 2005:172.
73. Kawaguchi Y: Fukuia kurodai kurodai. In Threatened Wildlife of Akita Prefecture 2002 -Red Data Book of Akita Prefecture. Edited by: Akita Prefecture. Akita Prefecture; 2002:203.

74. Masuda O, Uchiyama R: PISCES Ecological Field Gide Series 2: Freshwater Mollusks of Japan 2, Freshwater Mollusks of Japan Including Brackish Water Species Tokyo: PISCES; 2004.

75. Masuda O: Oncomelania nosophora. In Threatened Wildlife of Japan: Red Data Book 2nd ed., Land and Freshwater Mollusks. Volume 6. Edited by: Ministry of the Environment. Tokyo: Ministry of the Environment; 2005:68.

76. Suzuki T, Yamashita H, Miyagi T, Tatara Y: Cecina manchurica A. Adams, 1861 (Caenogastropoda: Pomatiopsidae) from Miyagi Prefecture, northern Japan. Molluscan Divers 2009, 1:5-11.

77. Japan Meteorological Agency: Mesh Climatic Data of Japan Tokyo: Japan Meteorological Business Support Center; 2002.

doi:10.1186/1471-2148-11-118

Cite this article as: Kameda and Kato: Terrestrial invasion of pomatiopsid gastropods in the heavy-snow region of the Japanese Archipelago. BMC Evolutionary Biology 2011 11:118.

\section{Submit your next manuscript to BioMed Central and take full advantage of:}

- Convenient online submission

- Thorough peer review

- No space constraints or color figure charges

- Immediate publication on acceptance

- Inclusion in PubMed, CAS, Scopus and Google Scholar

- Research which is freely available for redistribution

Submit your manuscript at www.biomedcentral.com/submit
C) Biomed Central 